\title{
An Empirical Study Of Hospitality Management Student Attitudes Toward Group Projects: Instructional Factors And Team Problems
}

Youngsoo Choi, University of Central Florida, USA

Heejung Ro, University of Central Florida, USA

\begin{abstract}
The development of positive attitudes in team-based work is important in management education. This study investigates hospitality students' attitudes toward group projects by examining instructional factors and team problems. Specifically, we examine how the students' perceptions of project appropriateness, instructors' support, and evaluation fairness influence their attitudes toward group projects. Also the effect of students' team problems on their attitudes toward group projects is examined. This study has highlighted the criticality of the instructor's role in group project management for achieving a high level of positive attitudes toward group projects among the hospitality management students.
\end{abstract}

Keywords: Group Project; Team Problems; Instructional Factors; Hospitality

\section{INTRODUCTION}

Not finance. Not strategy. Not technology. It is teamwork that remains the ultimate competitive advantage, both because it is so powerful and so rare. (Lencioni, 2002, p 7)

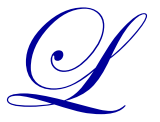

earning to work effectively in a group may be one of the most important interpersonal skills a person can develop because it will influence ones' employability, productivity and career success (Johnson \&Johnson, 1989). Collaborative group learning methods have been implemented and valued in a higher education setting because they are considered to be effective learning methods with educational and professional benefits while supporting the achievement of students' learning goals (Huff, Cooper, \& Jones, 2002; Wolfe \& Gould, 2001). According to a survey conducted by UCLA's Higher Education Research Institute, over one-third of the university courses use collaborative learning methods such as group projects (Illinois Online Network, 2010). Also, more than $80 \%$ of companies employ various types of workplace teams (Cohen \& Baily, 1997) and many employers rank the teamwork skill as one of the most important attributes they look for when interviewing graduates (Vance, 2007). Therefore, cooperative learning is advocated by the prospective employers of college graduates, accrediting agencies, and educators (Colbeck, Campbell, \& Bjorklund, 2000).

For management education, group projects have been ubiquitous because they help students develop skills and knowledge that are relevant to the real business world (Fellenz, 2006). Due to their unique and close relationship with the industry, hospitality management programs have emphasized the significance of group projects and heavily relied on this tool in order to best prepare their graduates for future professions. As hospitality business continues to encourage team-based work environments, use of groups has the capacity to create a high quality learning environment for students and may very well advance the educational practices of the hospitality management educators (Susskind \& Borchgrevink, 1999; Wolfe \& Gould, 2001). 
Previous studies on the hospitality management student group projects have focused on the effectiveness of the projects, particularly on the team dynamics and performance (Bartlett, Probber, \& Mohammed, 1999; LaLopa, Jacobs, \& Countryman, 1999; Susskind \& Borchgrevink, 1999). Assuming students' attitudes and behaviors at school will translate into those in their future workplace, instructors' efforts are geared toward encouragement of students' positive attitudes toward group projects as well as their performance. Yet, very little research has been conducted to investigate the instructor's role in influencing students' attitudes regarding group projects (Ettington \& Camp, 2002; Jeffrey, 2010a).

This study focuses on the attitudes of the hospitality management major students toward group projects by examining instructional factors and team problems. Specifically, we examine how the students' perceptions of project appropriateness, instructor's support, and evaluation fairness influence their overall attitudes toward a group project. We also examine the effect of students' team problems on their attitudes toward group projects. The findings of this research can provide useful insights for management educators in designing and guiding student group projects more effectively and to further nurture positive attitudes toward team-based work.

\section{LITERATURE REVIEW}

\section{Group Projects in Higher Education}

Group project assignments provide an excellent forum for experiential learning that incorporates skills necessary for employability, such as collaboration, problem solving, communication, shared vision, and decision making (Fellenz, 2006; Mahoney, 1999; Schultz, Wilson \& Hess, 2010). Students can gain a comprehensive understanding of various course concepts, be exposed to "real-world" applications outside of the class setting (Buckenmeyer, 2000), and learn group dynamics by working with other people (Tideswell, 2004). As student numbers continue to rise in parallel with declining resources, group projects become an attractive alternative to individual projects in higher education (Burdett, 2003). It helps faculty members increase productivity by lowering the grading burden (Williams, Beard, \& Rymer, 1991) and have more meaningful and intimate interactions with students by providing tailored advice (Aggarwal \& O'Brien, 2008).

While university faculties have been using group projects as an educational tool for many years, research on the effectiveness and student perceptions of group projects have produced mixed results. Some studies have shown that students' overall attitudes toward group projects are positive (Gottschall \& Garcia-Bayonas, 2008). The majority of students perceive a group project as a good method of learning (Rau \& Heyl, 1990) and value the development and sharing of heterogeneous viewpoints among them (Hagen, 1996). On the contrary, other researchers indicated that many students have unfavorable perceptions of group projects because of the negative group experiences (Feichtner \& Davis, 1984). The use of cooperative learning groups did not increase students' learning, motivation, or study time (Phipps, Phipps, Kask, \& Higgins, 2001) and group projects in undergraduate classes did not improve student performance (Kunkel \& Shafer, 1997).

In assessing students' perceptions of the group project experience, previous studies identified several influencing factors, such as project scope, group size, project time, perceived workload, project grade, peer evaluation, and social loafing (Aggarwal \& O’Brien, 2008; Brooks \& Ammons, 2003; Pfaff \& Huddleston, 2003). However, most of the previous studies used a particular class or a project by taking a case study approach. We believe that the students' overall perception of the group project experiences is important in order to understand their dispositional attitudes toward group projects, which will affect the professional practices of graduates in the future.

\section{Instructional Factors}

The degree of faculty guidance will play a significant role in determining whether the students find value in team-based learning (Livingston \& Lynch, 2000). However, in many classes, students are simply placed into groups with no preparation, resulting in students being ineffectively prepared for working in groups (Ettington \& Camp, 2002). According to Jeffrey (2010b), instructors can take roles of a facilitator, mentor, and monitor for students during the group projects. As a facilitator, the instructor provides structure and assistance with resources necessary for the students to take responsibility for learning. As a mentor, the instructor is expected to offer appropriate 
directions, suggestions, and insights to the students (King \& Behnke, 2005; Tideswell, 2004). Also, instructors need to monitor the group work, raise alerts, and intervene when a group is not functioning well. By reflecting on the key roles of instructors in group projects accompanied by a literature review, we focus on three instructional factors: (1) project appropriateness, (2) instructor's support, and (3) evaluation fairness.

First, instructors should develop group projects that provide students with good content and structure for learning and that are relevant to the course with a reasonable workload (Feichtner \& Davis, 1984; Pfaff \& Huddleston, 2003). Only when the instructor designs group projects based on these considerations, he/she can justify students' time commitment toward the group projects and help them have a meaningful learning experience.

Instructors' support refers to their effort in assisting students' group learning experiences and to emphasize the importance of group projects. Simply placing students into groups does not guarantee that they will magically learn how to effectively work together (Barker \& Franzak, 1997). In fact, having students work in groups without any instructional guidance may lead to dysfunctional group project experiences and negatively affect their attitudes toward future group projects (Chapman \& Van Auken, 2001). Instructors can help students develop positive attitudes toward group projects by conveying the value of team work, providing insights into group dynamics, and making attempts to limit the negative aspects of group projects (Chapman \& Van Auken, 2001). In addition, proper recognition and reflection of individual contributions to group work is important. Students seem to fear that their individual grades will be compromised or that the total amount of group work will not be distributed in a fair manner among the members of the group (Comer, 1995). The evaluation process is perceived as fair when it reflects individual contributions appropriately and the evaluation scheme should allow students to demonstrate their value to the group mostly via peer evaluation (Feichtner \& Davis, 1984; Pfaff \& Huddleston, 2003).

We expect that the student attitudes toward group projects will be influenced by students' perceptions of instructional factors - project appropriateness, instructor's support, and evaluation fairness. More favorable student perceptions and experience of these instructional factors will create more positive attitudes toward group projects. Therefore, we propose the following hypothesis:

Hypothesis 1: Instructional factors (project appropriateness, instructor's support, and evaluation fairness) positively influence the students' attitudes toward group projects.

Previous research indicated that many students have negative perceptions of group projects because of dysfunctional group experiences (Feichtner \& Davis, 1984). Team problems can result in student frustration and dissatisfaction due to various reasons, such as social loafing or free riding, different expectations about the assignment guidelines or learning outcomes, difficulty in coordinating schedules and workloads, and poor group dynamics or management process (Cumming, 2010; Gottschall \& Garcia-Bayonas, 2008; Hansen, 2006). Due to the fact that multiple students are collaborating as a group during a long period of time, the lack of contribution from certain members or the free rider issue have been frequently addressed as major concerns (Brooks \& Ammons, 2003; Snyder \& McNeil, 2008). Other studies also stress interpersonal communication (Payne, Monk-Turner, Smith, \& Sumter, 2006) and student perception of an effective collaborative experience (Anderson, 2005) as the direct and most significant factors affecting group cohesion and dynamics. Another potential concern is that working as a group is too time-consuming, especially when the group's coordinating efforts, including the arrangement of meetings, were managed inefficiently (Chapman \& Van Auken, 2001). Furthermore, working with others on a long-term task can be stressful and tends to create conflicts among the group members, who consequently will build a negative attitude toward team-based work (Lerner, 1995).

Hypothesis 2: Experience of team problems negatively influences the students' attitudes toward group projects.

\section{METHOD}

\section{Data Collection and Sample}

The self-instructed paper and pencil-based questionnaires were used for this study. A convenient sample of undergraduate hospitality management students at a large university in Florida was collected. Participants were 
instructed to answer the questions based on "all" of the group projects that they have had during their coursework in college. By asking about students' perceptions based on their overall experience during their tenure with the program as of the time of the survey, the study results are expected to be less subject to potential biases that might come from a particular project, group members, or an instructor. Students' overall values of a group project and team members can be shaped via many group project experiences with different members in various classes (Pineda, Barger, \& Lerner, 2009). The data collection from 10 classes, including guest service management, human resource management, and tourism management, yielded a total of 410 participants. Eleven of them were graduate students, 18 were from other majors outside of hospitality management, one student participated in the survey in two different classes, and one respondent left an excessive amount of questions unanswered. Excluding these 31 participants resulted in a total of 379 suitable samples for data analyses.

\section{Measures}

The instructional factors were assessed via three aspects: 1) group project appropriateness, 2) instructor's support, and 3) evaluation fairness. An appropriate group project is described as a project that is meaningful and relevant to the course with a reasonable workload (three items). Instructor's support is described as an instructor's effort to assist a group project by encouraging team building and providing feedback (five items). Evaluation fairness is described as a perceived fairness of the group project evaluation scheme that properly recognizes and reflects individual contributions of team members (two items). All 10 items are adopted from Hansen (2006) and measured by a 5 -point scale ( $1=$ never, $2=$ rarely, $3=$ in some classes, $4=$ in most classes, $5=$ in every class).

Team problems is described as problems experienced with team members, such as unequal contributions and skills and conflicts in personalities and decision-making. The four items are adopted from Levi, Rinzel, Cadiz, and Cacapit (1998) measured by a 5 -point scale $(1=$ never, $2=$ rarely, $3=$ in some classes, $4=$ in most classes, $5=$ in every class). The reliability coefficient of the construct was .820 .

Attitudes toward group projects is described as an individual's disposition toward group projects and is not specific to a certain project. The four items (e.g., I enjoy working in teams) were adopted from Friedman, Cox, and Maher (2008). These items are measured by a 5 -point scale ( $1=$ strongly disagree, $2=$ somewhat disagree, $3=$ neutral, $4=$ somewhat agree, $5=$ strongly agree). The reliability coefficient of the construct was .897 .

\section{RESULTS}

Seventy-five percent of the respondents were female students. The mean age of the respondents was 21.4 years with a range of 18 to 48 . The majority of respondents (55.4\%) were juniors, followed by seniors (24.0\%) and sophomores or freshmen $(20.6 \%)$. The reason why more than three-quarters of the respondents were either juniors or seniors is that the surveys were conducted mostly in the upper level classes. For ethnicity, $77.7 \%$ of the respondents were Caucasian, $11.8 \%$ were Hispanic, $4.4 \%$ were African American, $3.3 \%$ were Asian, and 2.8\% were other. Students' average hospitality work experience was 3.3 years. Most of the participants (73.4\%) were working for an average of 27.0 hours per week at the time of the survey. Students indicated that they have had approximately three group projects per semester $($ mean $=3.3$, median=3.0).

Ten items of instructional consideration were subject to a Principal Component Analysis (PCA) using a Varimax rotation technique for discriminant validity of the constructs. Three factors were identified with $66.11 \%$ of the total variance explained. The reliability coefficient values were .829 for project appropriateness, .757 for instructor's support, and .826 for evaluation fairness. The eigenvalues for the factors were 4.17 for instructor's support, 1.382 for project appropriateness and 1.06 for evaluation fairness. Also, the KMO measure of sampling adequacy (.813) and Bartlett's test of sphericity $(p=.000)$ indicate that a factor analysis is appropriate. The PCA results are provided in Table 1 and descriptive statistics, including a correlation matrix of all variables, are shown in Table 2. 
Table 1: Exploratory Factor Analysis of Instructional Factors

\begin{tabular}{|c|c|c|c|}
\hline & $\begin{array}{l}\text { Instructor's } \\
\text { Support }\end{array}$ & $\begin{array}{c}\text { Project } \\
\text { Appropriateness }\end{array}$ & $\begin{array}{c}\text { Evaluation } \\
\text { Fairness }\end{array}$ \\
\hline The teams have to submit one or more interim reports to the instructor. & .721 & & \\
\hline $\begin{array}{l}\text { The teams have at least some feedback from the instructor before } \\
\text { completing the final project. }\end{array}$ & .707 & & \\
\hline Team building and team development have been taught. & .662 & & \\
\hline The teams were given time to meet during at least several class periods. & .654 & & \\
\hline $\begin{array}{l}\text { The relevance of team projects and teamwork to your future career was } \\
\text { discussed. }\end{array}$ & .644 & & \\
\hline The projects were relevant to the course. & & .873 & \\
\hline The projects were meaningful to the course. & & .793 & \\
\hline The projects had reasonable workloads. & & .789 & \\
\hline $\begin{array}{l}\text { The project evaluation scheme allowed me to demonstrate my value to the } \\
\text { team. }\end{array}$ & & & .867 \\
\hline The project grade reflected individual's contribution appropriately. & & & .829 \\
\hline
\end{tabular}

Extraction Method: Principal Component Analysis. Rotation Method: Varimax with Kaiser Normalization.

Table 2: Descriptive Statistics of the Variables Correlations

\begin{tabular}{|c|c|c|c|c|c|c|c|c|}
\hline & \multicolumn{5}{|c|}{ Correlations } & \multirow[b]{2}{*}{ Mean } & \multirow[b]{2}{*}{$\begin{array}{l}\text { Standard } \\
\text { deviation }\end{array}$} & \multirow[b]{2}{*}{$\begin{array}{l}\text { Cronbach's } \\
\text { alpha }\end{array}$} \\
\hline & IS & PA & EF & TP & ATGP & & & \\
\hline IS & 1. & & & & & 3.049 & .762 & .757 \\
\hline $\mathrm{PA}$ & $.448 * *$ & 1. & & & & 3.759 & .729 & .829 \\
\hline $\mathrm{EF}$ & $.431 * *$ & $.483 * *$ & 1. & & & 3.528 & .895 & .826 \\
\hline $\mathrm{TP}$ & $-.285 * *$ & $-.412 * *$ & $-.480 * *$ & 1. & & 2.833 & .912 & .820 \\
\hline ATGP & $.475 * *$ & $.529 * *$ & $.437 * *$ & $-.363 * *$ & 1. & 3.358 & 1.044 & .897 \\
\hline
\end{tabular}

Note: IS=Instructor's support, $\mathrm{PA}=$ Project appropriateness, $\mathrm{EF}=$ Evaluation fairness, $\mathrm{PP}=$ team problems, $\mathrm{ATTP}=\mathrm{Attitudes}$ toward group projects

** Correlation is significant at the 0.01 level (2-tailed).

A multiple regression analysis was performed to assess the ability of the independent variables (i.e., project appropriateness, instructor's support, evaluation fairness, and team problems) to predict the level of student attitudes toward group projects. As hypothesized, we expect that the three instructional factors (project appropriateness, instructor's support, and evaluation fairness) will positively influence attitudes toward group projects, yet we expect team problems will negatively influence the dependent variable. The regression results show that the model is significant and explains a good proportion of variance in student attitudes $\left(F_{(4,371)}=55.24, p<.001\right.$, Adjusted $R^{2}$ $=.367)$.

As shown in Table 3, three instructional factors are statistically significant and have positive effects on students' overall attitudes toward group projects. The more often students had group projects that were well suited for the course, were supported by the instructor during the whole project process, and had fair evaluation methods, the more positive attitudes they had toward group projects. Standardized coefficient estimates show that project appropriateness $(b=.308)$ is a relatively stronger influence on the attitudes toward group projects, followed by instructor's support $(b=.250)$, and evaluation fairness $(b=.134)$. As expected, team problems negatively affect students' attitudes toward group projects $(b=-.098)$. In other words, students who have had more team problems from previous group projects show less favorable attitudes toward group projects.

Table 3: Regression Analysis Results

\begin{tabular}{lcccc}
\hline Independent Variables & Beta & t-statistic & Sig. & VIF \\
\hline (Constant) & & 1.11 & .27 & \\
\hline Instructor's support & .25 & 5.23 & .00 & \\
\hline Evaluation fairness & .13 & 2.59 & .01 & 1.35 \\
\hline Project appropriateness & .31 & 6.10 & .00 & 1.59 \\
\hline Team problems & -.10 & -2.04 & .04 & 1.50 \\
\hline Depe &
\end{tabular}

Dependent variable: Attitudes toward group projects; Adjusted $R^{2}=.367$ 


\section{DISCUSSIONS}

The ability to work efficiently and effectively with others in a group setting is not only important, but is mandatory for a student's success (Vance, 2007). Yet, in most cases, students' team process skills have not been well developed, which requires an instructor to actively help rather than passively observe the progress or ignore students' struggles (Ettington \& Camp, 2002). This study identified key instructional factors that influence the students' attitudes toward group projects in the hospitality management discipline. The results from a principal component analysis indicate that instructor's role can be categorized into three dimensions, such as project appropriateness, instructor's support and evaluation fairness. A multiple regression analysis reveals the positive influence from these three instructional factors and the negative effect from team problems on student attitudes toward group projects. Findings from this study may be useful for the hospitality management instructors who implement group projects in their courses, in terms of project design, development, and implementation, by providing insights into the instructional factors that significantly contribute to the effective collaborative experiences of students.

First, the study result solidifies the findings from the previous study (Hansen, 2006) that identified project appropriateness as an important factor affecting the students' overall attitudes toward group projects. When the students perceived a group project as a meaningful and relevant task in a course with a reasonable workload, they tended to develop positive attitudes toward that project (Davis, 1993). As Pizam and Shani (2009) demonstrated, hospitality practitioners characterize hospitality work as requiring a high degree of collaboration and teamwork among the employees. Therefore, hospitality management instructors should explain to students how the core class material is linked with the group project so that students perceive the group project as a meaningful component of coursework. Also, instructors may pre-design individual roles for group work in order to ensure reasonable and fair distribution of workload among the group members.

Second, instructor's support is also important for encouraging positive attitudes toward group projects. Instructors often focus on only the final product of the group project yet spend very little or no time on orientation to facilitate students' understanding of the group project's purpose. Instructors need to educate students about the benefits of working as a group (Chapman \& Van Auken, 2001) and provide a group process training (McGraw \& Tidwell, 2001). As noted by Holmer (2001), we suggest for management instructors to show their support by emphasizing the importance of group project process learning, teaching team development skills, and providing feedback for process quality.

At the beginning of the group process stage, instructors should emphasize that the group project is not just about completing a specific task for a class grade but about enhancing student ability to collaborate with other people in a group setting. Young college students have a very limited capacity to manage their feelings in a very dynamic and complex reality of team-based work (O'Connor \& Yballe, 2007). Hence, providing students with a group process training prior to the start of a project can lay the foundation for effective group experiences (McGraw \& Tidwell, 2001). Once the group project is initiated, certain class sessions can be allocated for the purpose of the group project in order to assist and encourage the success of the project. Since most group projects are long-term tasks spanning over more than several weeks or even a full semester, it would be beneficial to allocate certain class sessions and to set up a regular system of checking on the progress of the groups (Davis, 1993). What is equally or more important than setting up checkpoints is the constructive feedback from the instructor. Even though this may take an extra effort on the part of the instructor, it will be another persuasive message to the students regarding the value and significance of the group project as well as their success in the project. These days many instructors incorporate online components in the educational setting. Instructors can set up an online group discussion room to facilitate the groups' effective communication and to monitor the transparency of student collaboration. These types of in-class and online support can lead to greater student interest, satisfaction, and involvement in the course. Consequently, this effort may affect their evaluations of the group project, course and the instructor in a positive manner (Davis, 1993: Mosley \& Amponsah, 2007).

Third, students' perceptions of evaluation fairness affect their attitudes toward group projects. Although the fair assessment scheme of individual group members' contributions seems to be a mandate, it is not used with great regularity (Chapman \& Van Auken, 2001). In order to address these concerns, various assessment methods for 
evaluating individual contribution to the group can be considered. First, an instructor may give students an opportunity of peer evaluation at the mid-point and at the end of the project. In order to make these activities more meaningful, it is important to provide students with opportunities to incorporate their inputs in customizing evaluation criteria and procedures (Fellenz, 2006). If an instructor finds a severe anomaly in a group, such as multiple complaints about the lack of group communication or individual contributions, the group may be provided with an option to reorganize group membership or to conduct the project individually. Other ways to ensure that individual students are held accountable may include an introduction of individual spot quizzes and/or individual presentations of their group's progress (Johnson, Johnson, \& Smith, 1991 as cited in Davis, 1993).

Lastly, team problems negatively affect students' attitudes toward group projects. Any team problems can easily cause frustrations that lead to a dysfunctional team and low performance. Students may cope with the distressful situations by taking some actions (problem-focused coping), suffering through without taking any actions (emotion-focused coping), or ignoring the problem and even the project (avoidance coping) (Endler \& Parker, 1990). Instructors should guide students to use the appropriate problem-focused coping methods to diagnose the problem and make improvements instead of being passive or ignorant about the problem.

We also emphasize the critical role of cooperation and group dynamics in the team development. Instructors can provide an exercise where group members discuss group dynamics and expectations during their first meeting. Using such an exercise can reduce the likelihood of a group becoming dysfunctional and students having a negative experience (Chapman \& Van Auken, 2001). Also, the free-rider problem is one of the most common and serious issues that instructors need to address in group projects (Aggarwal \& O'Brien, 2008; Gottschall \& GarciaBayonas, 2008). Conducting evaluations at multiple points throughout the project may help the instructor to notice a possible serious problem in the group communications or in the lack of individual contributions (Brooks \& Ammons, 2003). Along with implementation of these tools to remedy the evaluation inequity concerns, instructors need to reinforce that the group project does simulate the "real world" and broach the topic of whether students believe these inequities will continue as they enter the industry. Workload inequities will continue to arise once students leave college and it should be emphasized that developing the skills and the proper attitudes to deal with such issues while in college will help students to better cope with them in the future (Chapman \& Van Auken, 2001).

\section{LIMITATIONS AND FUTURE RESEARCH}

This study emphasizes the role of instructors in the overall process of group projects, including project design, implementation, and evaluation. Even though this study offers important insights for the management instructors and researchers regarding their role in improving students' attitudes toward group projects, it has some limitations that may guide future research.

First, this study is based on the students' overall experience from multiple group projects throughout their various undergraduate hospitality management courses, which makes it impossible to analyze any causal relationships between the instructional factors and student attitudes toward a particular group project. Also, we only focused on four influencing factors in the study. However, attitudes toward group projects can be influenced by other factors including, but not limited to, individual differences based on socio-demographic and personality factors, individual motivation to learn, and other instructional factors, such as the group formation method (selfformation vs. assignment by the instructor). We suggest future research expand the study by including more influencing factors to increase explanatory power or designing an experimental study to explore causal relationships between the influencing factors and attitudes toward group projects. For other follow-up research, it would be meaningful to investigate how the instructional factors affect student groups' overall performance in group projects.

Second, the majority of our survey subjects were either in their junior or senior year at the time of data collection. Considering that students' overall attitudes toward group projects, based on their experiences, may change by their school year, diversification of student sample that includes freshmen and sophomores may help us to develop more comprehensive perspectives and insights regarding students' attitudes toward group projects. Due to the maturity and experiences, both in academics and in work, they may develop skills to deal with different challenges and, consequently, have less problems but more positive outcomes. On the contrary, some students may 
form unfavorable perceptions by school year if they had accumulated predominantly negative group work experiences. Negative experiences can be remembered stronger than the positive ones (Ito, Larsen, Smith, \& Cacioppo, 1998) and this negativity bias would exacerbate the students' attitudes toward group projects. Also, it is possible that there is a polarization of students' attitudes toward group projects depending on the school year. Whether it is positive or negative, a dispositional tendency of group projects at the beginning of a student's college experience may serve as an anchor and then the additional group project experiences can lead them to more salient attitudes toward group projects through selective information processing that is consistent with their preexisting perceptions. Therefore, it is highly recommended to conduct a type of longitudinal study that starts with an examination of college freshmen's perceptions of group projects prior to their first participation in collegiate group projects and tracks the dynamics of those students' perceptions as they progress to upper classes.

Third, our study samples were collected from a single institution located at a major tourism destination in the southeast of the U.S. Due to the proximity to the hospitality and tourism industry, the majority of the participants were already working with a significant amount of industry experience at the time of the survey. These students may have experienced teamwork in the workplace which may affect their attitudes toward group projects in school. Future research may explore the potential moderating effect of students' work experience. Also, unlike other management programs, there are a growing number of women who are pursuing hospitality programs and female students are often the majority in hospitality classes (Casado, 2009). Heavy emphasis on the applicant's work experience in the hiring process and female students' dominant enrollment may provide different challenges for students, such as work-school balance, group dynamics, and group leadership. Future research can examine the similarities and differences in the students' group project perceptions in different management programs (e.g., hospitality management and other business management). It is not uncommon for some business schools to have hospitality management programs within their program. Understanding the differences in their needs and perceptions regarding group projects can help instructors' approach to different types of students.

\section{AUTHOR INFORMATION}

Youngsoo Choi, Ph.D. is an assistant professor at Rosen College of Hospitality Management, University of Central Florida. His areas of research interest are tourism destination management/marketing, hospitality human resource management issues, and hospitality education. E-mail: youngsoo.choi@ucf.edu (Corresponding author)

Heejung Ro, Ph.D. is an assistant professor at Rosen College of Hospitality Management, University of Central Florida. Her research focuses on consumer behavior, services marketing and management, and hospitality education. Her SOTL research interests include student group project perceptions and learning styles.

\section{REFERENCES}

1. Aggarwal, P. \& O’Brien, C.L. (2008). Social loafing on group projects- structural antecedents and effect on student satisfaction. Journal of Marketing Education, 30(3), 255-264.

2. Anderson, J. R. (2005). The relationship between student perceptions of team dynamics and simulation game outcomes: an individual-level analysis. Journal of Education for Business, 81(2), 85-90.

3. Barker, R. T., \& Franzak, F. J. (1997). Team building in the classroom: Preparing students for their organizational future. Journal of Technical Writing and Communication, 27, 303-315.

4. Bartlett, L. B., Probber, J., \& Mohammed, S. (1999). The effect of team-building on team process and performance. Journal of Hospitality \& Tourism Research, 23(3), 299-311.

5. Brooks, C.M., \& Ammons, J.L. (2003). Free riding in group projects and the effects of timing, frequency, and specificity of criteria in peer assessments. Journal of Education for Business, 78(5), 268-272.

6. Buckenmeyer, J.A. (2000). Using teams for class activities: making courses/classroom team work. Journal of Education for Business, 76(2), 98-107.

7. Burdett, J. (2003). Making groups work: university students' perceptions. International Education Journal, 4(3), 177-191.

8. Casado, M. (2009). Cultural diversity in higher education hospitality programs. International CHRIE Conference - Refereed Track, Retrieved from http://scholarworks.umass.edu/cgi/viewcontent.cgi?article $=1004 \&$ context=refereed 
9. Chapman, K. J., \& Van Auken, S. (2001). Creating positive group project experiences: an examination of the role of the instructor on students' perceptions of group projects. Journal of Marketing Education, 23(2), 117-127.

10. Cohen, S. G. \& Baily, D.E. (1997). What makes team work: group effectiveness research form the shop floor to the executive suite. Journal of Management, 23(3), 239-290.

11. Colbeck, C. L., Campbell, S. E., \& Bjorklund, S. A. (2000). Grouping in the dark: what college students learn from group projects. Journal of Higher Education, 71(1), 60-83.

12. Comer, D. R. (1995). A model of social loafing in real work groups. Human Relations, 48(6), 647-668.

13. Cumming, J. (2010). Student-initiated group management strategies for more effective and enjoyable group work experiences. Journal of Hospitality, Leisure, Sport \& Tourism Education, 9(2), 31-45.

14. Davis, B.G. (1993). Tools for Teaching, San Francisco, CA: Jossey-Bass. Retrieved from http://teaching.berkeley.edu/bgd/collaborative.html

15. Endler, N. S. \& Parker, J. D. (1990). Multidimensional assessment of coping: a critical evaluation. Journal of Personality and Social Psychology, 58 (May), 844-854.

16. Ettington D.R. \& Camp, R.R. (2002). Facilitating transfer of skills between group projects and work teams. Journal of Management Education, 26(4), 356-379.

17. Feichtner, S.B. \& Davis, B.A. (1984). Why some groups fail: a survey of students' experience with learning groups, Organizational Behavior Teaching Review, 9, 75-88.

18. Fellenz, M.R. (2006). Toward fairness in assessing student groupwork: a protocol for peer evaluation of individual contributions. Journal of Management Education, 30(4), 570-591.

19. Friedman, B.A., Cox, P. L., \& Maher, L. E. (2008). An expectancy theory motivation approach to peer assessment. Journal of Management Education, 32(5), 580-612.

20. Gottschall, H., \& Garcia-Bayonas, M. (2008). Student attitudes towards group work among undergraduates in business administration, education and mathematics. Education Research Quarterly, 32(1), 3-28.

21. Hagen, J.W. (1996). Student perceptions of cooperative learning in human service education. Human Service Education, 16(1), 47-56.

22. Hansen, R.S. (2006). Benefits and problems with student teams: suggestions for improving team projects. Journal of Education for Business, 82(1), 11-19.

23. Holmer, L. L. (2001). Will we teach leadership or skilled incompetence? The challenge of student project teams. Journal of Management Education, 25(5), 590-605.

24. Huff, L.C., Cooper, J. \& Jones, W. (2002). The development and consequences of trust in student project groups. Journal of Marketing Education, 24, 24-34.

25. Illinois Online Network. (2010). Instructional strategies for online courses. Retrieved December 15, 2011, from http://webcache.googleusercontent.com/search?q=cache:3vdeK8sbSfoJ:www.ion.uillinois.edu/resources/tut orials/pedagogy/instructionalstrategies.asp+instructor+role+in+group+project\&cd=17\&hl=en\&ct=clnk\&gl $=\mathrm{us}$

26. Ito, T.A., Larsen, J.T., Smith, N.K., \& Cacioppo, J.T. (1998). Negative information weighs more heavily on the brain: the negativity bias in evaluative categorizations. Journal of Personality and Social Psychology, 75(4), 887-900.

27. Jeffrey, T.R. (2010a). Learner and instructor perceptions regarding the role of the instructor in collaborative group learning. Proceedings of the $40^{\text {th }}$ annual conference of the International Society for Exploring Teaching and Learning (ISETL), Nashville, TN, 119-126. Retrieved from http://www.isetl.org/conference/ISETL10Proceedings.pdf

28. Jeffrey, T.R. (2010b). Instructional Design and Technology Student and Instructor Perceptions Regarding Collaborative Learning Groups. Doctoral Dissertation, Virginia Polytechnic Institute and State University, Blacksburg, VA. Retrieved from http://scholar.lib.vt.edu/theses/.../etd-03232010.../Jeffrey TR D 2010.pdf

29. Johnson, D.W., \& Johnson, R.T. (1989). Leading the cooperative school, Edina, MN: Interaction.

30. King, P. E., \& Behnke, R. R. (2005). Problems associated with evaluating student Performance in groups. College Teaching, 53(2), 57-61.

31. Kunkel, J.G. \& Shafer, W.E. (1997). Effects of student team learning in undergraduate auditing courses. Journal of Education for Business, 72(4), 197-200. 
32. LaLopa, J.M., Jacobs, J.W., \& Countryman, C. (1999). The effects of student teams on quiz score performance given a performance-based incentive package. Journal of Hospitality and Tourism Education, 11(2/3), 25-30.

33. Lencioni, P. (2002). The five dysfunctions of a team: A leadership fable. San Francisco, CA: Jossey-Bass.

34. Lerner, L. D. (1995). Making student groups work. Journal of Management Education, 19(1), $123-125$.

35. Levi, D., Rinzel, L., Cadiz, D., \& Cacapit, M. (1998). Effects of education and team projects on students attitudes toward team work. ERIC: ED421072.

36. Livingston, D. \& Lynch, K. (2000). Group project work and student-centered active learning: two different experiences, Studies in Higher Education, 25(3), 325-345.

37. Mahoney, J.F. (1999). Teaching management skills using team building in quantity food. Journal of Hospitality and Tourism Education, 11(1), 12-17.

38. McGraw, P., \& Tidwell, A. (2001). Teaching group process skills to MBA students: A short workshop. Education + Training, 43(2/3), 162-170.

39. Mosley, G.G., \& Amponsah, D.K. (2007). U.S. and non-U.S. students' perceptions of group project experience in marketing classes. Troy University Business and Economic Review, 31(1), 7-10.

40. O’Connor, D., \& Yballe, L. (2007). Team leadership: critical steps to great projects. Journal of Management Education, 31(2), 292-312.

41. Payne, B. K., Monk-Turner, E., Smith, D., \& Sumter, M. (2006). Improving group work: Voices of students. Education, 126(3), 441-448.

42. Pfaff, E., \& Huddleston, P. (2003). Does it matter if I hate teamwork? What impacts student attitudes toward teamwork. Journal of Marketing Education, 25(1), 37-45.

43. Phipps, M., Phipps, C., Kask, S., \& Higgins, S. (2001). University students' perception of cooperative learning: Implications for administrators and instructors. The Journal of Experiential Education, 24(1), 1421.

44. Pineda, R.C., Barger, B., \& Lerner, L.D. (2009). Exploring differences in student perceptions of teamwork: the case of U.S. and Lithuanian students. Journal of International Business and Cultural Studies, 1, 50-58.

45. Pizam, A., \& Shani, A. (2009). The nature of the hospitality industry: present and future managers' perspectives. Anatolia: An International Journal of Tourism and Hospitality Research, 20(1), 134-150.

46. Rau, W., \& Heyl, B.S. (1990). Humanizing the college classroom: Collaborative learning and social organization among students. Teaching Sociology, 18(2), 141-155.

47. Schultz, J. L., Wilson, J. R., \& Hess, K. C. (2010). Team-based Classroom Pedagogy Reframed: The Student Perspective, American Journal of Business Education, 3(7), 17-24.

48. Snyder, L. G., \& McNeil, K. R. (2008). Enhancing students' perceptions of collaborative projects through the use of pre-group instruction methods. Research in Higher Education Journal, 1, Retrieved from http://www.aabri.com/manuscripts/08067.pdf

49. Susskind, A.M. \& Borchgrevink, C.P. (1999). Team-based interaction in the foodservice instructional laboratory an exploratory model of team composition, team-member interaction, and performance. Journal of Hospitality \& Tourism Education, 10(4), 22-29.

50. Tideswell, C. (2004). A student perspective on the use of team-based assessment to achieve the requirement to be created: a study of entrepreneurship students. Journal of Teaching in Travel and Tourism, 4(4), 1-22.

51. Vance, K. (2007). Walking the talk: working on a faculty interdisciplinary team to develop Internet workspaces for student project teams, Proceedings of the 2007 Association for Business Communication Annual Convention, Retrieved from http://businesscommunication.org/wpcontent/uploads/2011/04/16ABC07.pdf

52. Williams, D.L., Beard, J.D., \& Rymer, J. (1991). Team projects: achieving their full potential. Journal of Marketing Education, 13, 45-53.

53. Wolfe, K. \& Gould, R. (2001). Insights on team-based learning, Journal of Hospitality \& Tourism Education, 13, (3/4), 87-96. 